\title{
PENGARUH KONSERVATISME AKUNTANSI TERHADAP ABNORMAL RETURN SAHAM PADA SAAT PENGUMUMAN SEASONED EQUITY OFFERINGS
}

\author{
Vinny Violetta \\ Jenjang Sri Lestari
}

Program Studi Akuntansi, Fakultas Ekonomi, Universitas Atma Jaya Yogyakarta

Jalan Babarsari 43-44, Yogyakarta

\section{Intisari}

Penelitian ini bertujuan untuk mengetahui pengaruh konservatisme terhadap abnormal return saham pada saat pengumuman Seasoned Equity Offerings (SEO) pada perusahaan yang terdaftar di BEI. Penelitian ini dilakukan untuk melihat pengaruh dari konservatisme akuntansi terhadap abnormal return pada saat pengumuman SEO. Penelitian ini juga menggunakan variabel kontrol berupa size dan leverage.

Sampel dalam perusahaan ini menggunakan 39 perusahaan yang terdaftar di BEI dan melakukan penawaran saham tambahan selama periode 2011-2013. Hasil dari penelitian menunjukkan bahwa konservatisme memiliki pengaruh positif signifikan terhadap abnormal return saham pada saat pengumuman SEO. Variabel kontrol leverage berpengaruh negatif signifikan terhadap abnormal return saham pada saat pengumuman SEO. Sedangkan size tidak memiliki pengaruh terhadap abnormal return saham pada saat pengumuman SEO.

\section{Kata Kunci : Konservatisme, Abnormal Return.}

\section{Pendahuluan}

Persaingan usaha yang kian meningkat menuntut setiap perusahaan untuk meningkatkan kinerja sehingga dapat menciptakan daya saing yang kuat di antara para pesaingnya. Sebagian besar perusahaan berusaha untuk melakukan ekspansi terhadap usahanya baik lokal maupun internasional sehingga membutuhkan tambahan dana yang cukup besar. Pendanaan dapat dilakukan dengan berbagai cara, salah satunya dengan melakukan penawaran saham tambahan yang biasa disebut dengan SEO.

Investor yang memutuskan untuk berinvestasi pada suatu perusahaan pada hakikatnya dengan harapan memperoleh keuntungan di masa mendatang (Halim, 2005). Untuk melakukan investasi diperlukan pengetahuan untuk memahami dan menganalisis kinerja perusahaan melalui informasi yang disajikan pada laporan keuangan. Hal ini menjadikan laporan keuangan menjadi sarana bagi investor untuk memantau kinerja dari manajemen dalam mengelola sumber daya perusahaan.

Menurut teori keagenan yang dikemukakan oleh Jensen and Meckling (1976), terdapat perbedaan kepentingan antara manajer dan investor sehingga menyebabkan adanya asimetri informasi antara kedua pihak tersebut. Pihak manajemen mengandalkan pengetahuan yang dimilikinya untuk memenuhi kepentingan pribadinya. Upaya untuk membuat laporan keuangan terlihat lebih baik dikarenakan terdapat hubungan positif antara informasi akuntansi dan harga saham perusahaan yang bersangkutan. Semakin bagus informasi yang dipublikasikan, maka semakin tinggi pula harga saham perusahaan tersebut (Sulistyanto, 2008: 72). 
Berdasarkan SFAC No. 2 Paragraf No. 95, konservatisme merupakan reaksi kehati-hatian terhadap ketidakpastian dan resiko yang melekat pada suatu bisnis. Setiap perusahaan akan menghadapi ketidakpastian dalam kegiatan usahanya, sehingga diperlukan kehati-hatian dalam mengakui gains dan losses. Lo (2005) juga menyatakan bahwa konservatisme merupakan suatu pandangan pesimistik dalam akuntansi. Penerapan konservatisme sebagai penyeimbang sikap optimistik dan membatasi tindakan oportunistik manajer dalam memanfaatkan asimetri informasi yang terjadi, khususnya pada saat perusahaan ingin melakukan penawaran saham tambahan. Dengan demikian, tindakan manajer untuk melakukan manipulasi atas kinerjanya juga dapat dibatasi.

Menurut Beaver dan Ryan (2000), perusahaan yang menerapkan konservatisme cenderung menyajikan laporan keuangan dengan nilai buku ekuitas lebih rendah dibandingkan nilai pasarnya. Menurut Gunanta (2013), investor yang dapat menerima sinyal dan mengoreksi undervalue ekuitas perusahaan justru akan menilai ekuitas perusahaan dengan harga yang lebih tinggi. Perusahaan yang mengungkapkan secara undervalue juga menimbulkan rasa yang lebih aman bagi investor karena perusahaan yang terkait masalah earning management biasanya adalah perusahaan yang melakukan overstatement (Watts, 2003). Oleh sebab itu, dengan penerapan konservatisme dapat menjadi sinyal positif bagi investor sehingga meningkatkan harga pasar saham perusahaan (Gunanta, 2013). Dengan meningkatnya harga saham perusahaan, maka return saham yang akan diperoleh juga semakin tinggi karena return saham merupakan selisih dari harga saham sekarang dan harga saham sebelumnya (Jogiyanto, 2011).

Berdasarkan latar belakang yang telah dikemukakan di atas, maka permasalahan yang diangkat dalam penelitian ini adalah sebagai berikut :

1. Apakah konservatisme akuntansi berpengaruh positif terhadap abnormal return saham pada saat pengumuman SEO?

\section{Landasan Teori dan Pengembangan Hipotesis}

SFAC No. 2, Paragraf No. 95 menyatakan bahwa : "Conservatism is a prudent reaction to uncertainty to try to ensure that uncertainties and risks inherent in business situations are adequately considered". Konservatisme merupakan konsep dasar yang menjadi landasan penentuan perlakuan akuntansi dalam kondisi ketidakpastian. Secara umum, konservatisme akan segera mengakui kerugian dan menunda pengakuan pendapatan hingga memenuhi kriteria untuk diakui sebagai pendapatan.

Watts (2003) mendefinisikan konservatisme sebagai prinsip kehati-hatian dalam pelaporan keuangan dimana perusahaan tidak terburu-buru dalam mengakui dan mengukur aset dan laba serta segera mengakui kerugian dan hutang yang mempunyai kemungkinan akan terjadi. Dalam penerapan prinsip ini terdapat perbedaan dari tingkat verifikasi, dimana berita baik sebagai gains akan diverifikasi pada tingkat yang lebih tinggi dibandingkan dengan mengakui berita buruk sebagai losses (Basu, 1997).

Menurut Watts (2003), terdapat tiga pendekatan dalam pengukuran konservatisme, yaitu net asset measures, Earnings and accruals measures, dan 
Earnings/stock measures. Penelitian ini menggunakan net asset measures karena sampel yang digunakan tidak hanya perusahaan manufaktur, melainkan seluruh perusahaan yang melakukan penawaran saham tambahan.

Menurut Jogiyanto (2011: 557), abnormal return atau excess return merupakan kelebihan dari return yang sesungguhnya terjadi terhadap return normal. Return normal merupakan return ekspektasian atau return yang diharapkan oleh investor. Dengan demikian, return tidak normal (abnormal return) adalah selisih antara return sesungguhnya yang terjadi dengan return ekspektasian.

Return realisasian atau return sesungguhnya merupakan return yang terjadi pada waktu ke-t yang merupakan selisih harga sekarang relatif terhadap harga sebelumnya. Return ekspektasian merupakan return yang harus diestimasi. Terdapat tiga model untuk menghitung return ekspektasian, yaitu mean-adjusted model, market model, dan market-adjusted model. Dalam penelitian ini, model yang digunakan adalah market-adjusted model.

Menurut Bapepam LK, penawaran saham tambahan di Indonesia terdiri dari penawaran saham dengan Hak Memesan Efek Terlebih Dahulu (HMETD) dan penawaran saham tanpa HMETD. Penawaran saham tambahan dengan HMETD (Hak Memesan Eefek Terlebih Dahulu) diatur dalam Keputusan Ketua Bapepam Nomor Kep - 26/PM/2003 Peraturan Nomor IX.D.1. HMETD atau yang biasa dikenal dengan bukti right atau right merupakan sekuritas yang memberikan hak kepada pemegang saham lama untuk membeli saham baru perusahaan pada harga yang telah ditetapkan selama periode tertentu (Tandelilin, 2010:37).

Penawaran saham tambahan tanpa HMETD atau yang biasa disebut dengan general cash offering diatur dalam keputusan Ketua Bapepam Nomor Kep 429/BL/2009 Peraturan Nomor IX.D.4. Menurut Sulistyanto (2008), penawaran ini biasanya disebut dengan second offerings, third offerings, dan sebagainya yang merupakan penawaran saham tambahan dengan menjual saham kepada setiap investor yang ingin membelinya, tidak hanya kepada pemegang saham lama.

Menurut Jogiyanto (2011), investor akan memutuskan kapan untuk membeli, mempertahankan atau menjual saham suatu perusahaan berdasarkan informasi yang tersedia. Ketika laporan keuangan suatu perusahaan disajikan dengan berdasarkan pada konservatisme akan memberikan sinyal positif kepada para investor karena dapat lebih dipercaya dan relevan dalam pengambilan keputusan untuk berinvestasi. Kemudian, pada saat perusahaan tersebut melakukan pengumuman atas penawaran tambahan, investor yang dapat mengoreksi informasi yang tersedia dengan benar akan bereaksi sehingga menyebabkan jumlah permintaan dan penawaran akan berubah (Jogiyanto, 2011). Perubahan tersebut menyebabkan perubahan harga saham perusahaan dan ketika investor dapat menangkap sinyal positif atas informasi yang disediakan perusahaan, harga saham perusahaan akan meningkat yang pada akhirnya memberikan abnormal return positif bagi perusahaan pada saat itu.

\section{$\mathrm{H}_{1}$ : Konservatisme akuntansi memiliki pengaruh positif terhadap return saham pada saat pengumuman SEO.}




\section{Metode Penelitian}

Penelitian yang dilakukan merupakan penelitian empiris dengan pengujian hipotesis untuk membuktikan pengaruh konservatisme akuntansi terhadap abnormal return saham pada saat pengumuman SEO. Populasi yang digunakan dalam penelitian ini adalah seluruh perusahaan yang terdaftar di Bursa Efek Indonesia. Pemilihan sampel dalam penelitian dilakukan dengan purposive sampling untuk mendapatkan sampel yang representatif sesuai kriteria yang ditentukan. Kriteria yang digunakan dalam pemilihan sampel adalah :

1. Perusahaan yang terdaftar di BEI dan melakukan SEO pada periode 2011-2013.

2. Perusahaan yang laporan keuangan, surat hasil keputusan RUPSLB, dan daftar harga saham dapat diperoleh melalui yahoofinance, idx.co.id, ICMD, dan public domain lainnya yang dapat diakses dengan mudah.

Dalam penelitian ini menggunakan variabel dependen, variabel independen, dan variabel kontrol. Variabel dependen dalam penelitian ini adalah abnormal return saham pada saat pengumuman SEO. Dalam penelitian ini, abnormal return diukur dengan mengurangan return realisasian dengan return ekspektasian. Return ekspektasian dihitung dengan menggunakan market-adjusted model, yaitu dengan mengurangkan IHSG pada tanggal $t$ dengan IHSG pada tanggal $t_{-1}$ kemudian dibagi dengan IHSG pada tanggal $\mathrm{t}_{-1}$.

Variabel independen yang digunakan dalam penelitian ini adalah konservatisme akuntansi. Dalam penelitian ini, konservatisme diukur dengan menggunakan pendekatan net asset measures yang menggunakan model market to book ratio, yaitu dengan mengalikan jumlah saham beredar dan harga penutupan saham kemudian dibagi dengan total ekuitas. Penelitian ini juga menggunakan variabel kontrol berupa size yang diukur dengan natural log total aset dan leverage yang diukur dengan total liabilitas dibagi dengan total aset.

Penelitian ini akan menggunakan beberapa pengujian yaitu uji normalitas, uji asumsi klasik, dan uji hipotesis. Uji asumsi klasik terdiri dari uji multikolinearitas, uji heterskedastisitas, dan uji autokorelasi. Model regresi berganda yang akan diteliti adalah :

$$
\text { SEOCAR }=\alpha+\beta_{1} \text { CONSV }+\beta_{2} \text { SIZE }+\beta_{3} L E V+\varepsilon .
$$

\section{Analisis Data dan Pembahasan}

Sampel yang digunakan dalam penelitian ini berjumlah 39 perusahaan dengan total 42 pengamatan. Data tersebut ternyata tidak terdistribusi dengan normal, sehingga peneliti melakukan trimming dan sampel pengamatan menjadi 41 pengamatan.

Tabel 4.2 di bawah ini menunjukkan hasil dari statistik deskriptif untuk variabel konservatisme (CONSV), size (SIZE), leverage (LEV), dan abnormal return pada saat pengumuman SEO. 
Tabel 4.2

\section{Statistik Deskriptif}

Descriptive Statistics

\begin{tabular}{|l|r|r|r|r|r|}
\hline & N & Minimum & Maximum & \multicolumn{1}{|l|}{ Mean } & Std. Deviation \\
\hline SEOCAR & 41 &,- 72289 &, 88760 &, 0110789 &, 21756373 \\
SIZE & 41 & $-725,50422$ & 78,29761 & $-14,8938412$ & 114,61393296 \\
LEV & 41 & 21,84240 & 32,40345 & 28,1010169 & 2,60602221 \\
Valid N (listwise) & 41 &, 03796 & 2,99814 &, 7838115 &, 58812390 \\
\hline
\end{tabular}

Peneliti menggunakan uji normalitas untuk menguji normal atau tidaknya distribusi data yang digunakan. Hasil pengujian dengan menggunakan 42 sampel pengamatan menghasilkan nilai Asymp. Sig. (2-tailed) adalah 0,021, dimana hasil tersebut lebih kecil dari 0,05 sehingga hasilnya dinyatakan tidak terdistribusi dengan normal. Kemudian peneliti melakukan trimming dengan menghilangkan data outlier. Setelah melakukan trimming, sampel penelitian menjadi 41 dan menunjukkan hasil bahwa nilai Asymp. Sig. (2-tailed) adalah 0,245 yang berarti bahwa data tersebut telah terdistribusi secara normal karena lebih besar dari 0,05 .

Tabel 4.4

\section{Uji Normalitas Setelah Trimming}

One-Sample Kolmogorov-Smirnov Test

\begin{tabular}{|ll|r|}
\hline & & $\begin{array}{r}\text { Unstandardiz } \\
\text { ed Residual }\end{array}$ \\
\hline $\mathrm{N}$ & & 41 \\
Normal Parameters & a,b & Mean \\
Most Extreme & Std. Deviation & .0000000 \\
Differences & Absolute & .16119774 \\
& Positive & .160 \\
Kolmogorov-Smirnov Z & Negative & .160 \\
Asymp. Sig. (2-tailed) & & -.123 \\
\hline
\end{tabular}

a. Test distribution is Normal.

b. Calculated from data.

Model regresi yang digunakan dalam penelitian ini dikatakan bebas dari multikolinearitas, karena ketiga variabel yang digunakan memiliki nilai VIF di bawah 5 dan tolerance di atas 0,5 . Berikut ini adalah hasil dari pengujian multikolinearitas : 
Tabel 4.5

\section{Uji Multikolinearitas}

\begin{tabular}{|c|c|c|c|}
\hline \multicolumn{4}{|c|}{ Coefficients } \\
\hline \multirow{2}{*}{\multicolumn{2}{|c|}{ Model }} & \multicolumn{2}{|c|}{ Collinearity Statistics } \\
\hline & & Tolerance & VIF \\
\hline \multirow[t]{3}{*}{1} & CONSV & .992 & 1.008 \\
\hline & SIZE & .902 & 1.109 \\
\hline & LEV & .904 & 1.106 \\
\hline
\end{tabular}

a. Dependent Variable: SEOCAR

Penelitian ini melakukan pengujian heteroskedastisitas dengan Uji Glejser. Hasil dari pegujian mennunjukkan bahwa model regresi yang digunakan dalam penelitian ini dinyatakan tidak terjadi heteroskedastisitas karena semua variabel memiliki nilai signifikansi di atas 0,05. Berikut ini hasil dari pengujian heteroskedastisitas :

\section{Tabel 4.6}

\section{Uji Heteroskedastisitas}

Coefficients

\begin{tabular}{|c|c|c|c|c|c|c|}
\hline \multirow{2}{*}{\multicolumn{2}{|c|}{ Model }} & \multicolumn{2}{|c|}{$\begin{array}{c}\text { Unstandardized } \\
\text { Coefficients }\end{array}$} & \multirow{2}{*}{$\begin{array}{l}\text { Standardized } \\
\text { Coefficients } \\
\text { Beta }\end{array}$} & \multirow[b]{2}{*}{$\mathrm{t}$} & \multirow[b]{2}{*}{ Sig. } \\
\hline & & $\mathrm{B}$ & Std. Error & & & \\
\hline \multirow[t]{4}{*}{1} & (Constant) & -.035 & .236 & & -.148 & .883 \\
\hline & CONSV & .000 & .000 & .128 & .799 & .429 \\
\hline & SIZE & .004 & .008 & .074 & .443 & .660 \\
\hline & LEV & .049 & .035 & .232 & 1.388 & .173 \\
\hline
\end{tabular}

a. Dependent Variable: abs

Pengujian autokorelasi dilakukan dengan menggunakan metode Durbin Watson. Hasil dari pengujian menghasilkan nilai Durbin Watson sebesar 1,813 yang akan dibandingkan dengan tabel Durbin Watson dengan signifikansi 5\% dan jumlah sampel 41. Hasil dari pengujian tersebut menunjukkan bahwa nilai 1,813 terletak di antara 1,6603 dan 2,3397 sehingga dapat disimpulkan bahwa tidak terjadi autokorelasi dalam model tersebut. Berikut ini hasil dari pengujian autokorelasi :

\section{Tabel 4.7}

\section{Uji Autokorelasi}

\begin{tabular}{|l|r|r|r|r|c|}
\multicolumn{7}{c|}{ Mode I Sum marb } \\
\hline Model & $\mathrm{R}$ & R Square & $\begin{array}{c}\text { Adjusted } \\
\text { R Square }\end{array}$ & $\begin{array}{c}\text { Std. Error of } \\
\text { the Estimate }\end{array}$ & $\begin{array}{c}\text { Durbin- } \\
\text { Watson }\end{array}$ \\
\hline 1 & $.672^{\mathrm{a}}$ & .451 & .407 & .16760543 & 1.813 \\
\hline
\end{tabular}

a. Predictors: (Constant), LEV, CONSV, SZE

b. Dependent Variable: SEOCAR 
Pengujian hipotesis dalam penelitian ini menggunakan pengujian regresi linear berganda karena terdapat lebih dari satu variabel independen dalam model regresi. Pengujian ini bertujuan untuk menguji pengaruh konservatisme sebagai variabel independen, size dan leverage sebagai variabel kontrol terhadap abnormal return saham pada saat SEO. Berikut ini merupakan hasil dari pengujian regresi berganda :

Tabel 4.8

\section{Uji Hipotesis}

Coefficie nts

\begin{tabular}{|c|c|c|c|c|c|c|}
\hline \multirow{2}{*}{\multicolumn{2}{|c|}{ Model }} & \multicolumn{2}{|c|}{$\begin{array}{c}\text { Unstandardized } \\
\text { Coefficients }\end{array}$} & \multirow{2}{*}{$\begin{array}{c}\text { Standardized } \\
\text { Coefficients }\end{array}$} & \multirow[b]{2}{*}{$\mathrm{t}$} & \multirow[b]{2}{*}{ Sig. } \\
\hline & & $B$ & Std. Error & & & \\
\hline \multirow[t]{4}{*}{1} & (Constant) & -.182 & .315 & & -.579 & .566 \\
\hline & CONSV & .001 & .000 & .367 & 3.004 & .005 \\
\hline & SIZE & .012 & .011 & .148 & 1.152 & .257 \\
\hline & LEV & -.182 & .047 & -.493 & -3.846 & .000 \\
\hline
\end{tabular}

a. Dependent Variable: SEOCAR

Hasil dari pengujian menunjukkan bahwa variabel konservatsime memiliki nilai signifikansi sebesar 0,005. Nilai signifikansi variabel konservatisme lebih kecil dari 0,05 sehingga dapat disimpulkan bahwa variabel konservatisme berpengaruh positif singnifikan terhadap abnormal return saham pada pengumuman saat SEO. Hal tersebut berarti bahwa semakin konservatif suatu perusahaan dalam penyusunan laporan keuangannya, maka abnormal return saham pada saat pengumuman SEO juga akan semakin tinggi.

Ketika suatu perusahaan memilih untuk menggunakan metode yang cenderung berhati-hati dalam mengakui laba, hal tersebut dapat menjadi sinyal positif bagi para investor karena informasi yang disajikan dapat lebih dipercaya dan relevan dalam pengambilan keputusan berinvestasi. Investor akan merasa lebih aman karena perusahaan hanya mengungkapkan laba yang telah terealisasi. Dengan demikian, ketika terdapat corporate action berupa pengumuman penawaran saham tambahan, para investor akan bereaksi dengan melakukan transaksi terhadap saham yang dikeluarkan oleh perusahaan tersebut. Reaksi tersebut menyebabkan perubahan dalam jumlah permintaan dan penawaran yang pada akhirnya juga berdampak pada harga saham perusahaan. Harga saham perusahaan akan meningkat ketika investor memiliki respon yang positif terhadap aksi yang dilakukan oleh perusahaan dan hal tersebut juga akan meningkatkan abnormal return saham perusahaan pada saat itu.

Dalam penelitian ini peneliti juga menggunakan dua variabel kontrol, yaitu size dan leverage. Variabel size memiliki nilai signifikansi 0,257 yang berarti bahwa variabel size tidak berpengaruh secara signifikan terhadap abnormal return saham pada saat SEO. Kemudian, variabel leverage memiliki nilai signifikansi 0,000 yang berarti bahwa leverage memiliki pengaruh negatif signifikan terhadap abnormal return saham pada saat pengumuman SEO. 


\section{Tabel 4.9}

\section{Uji Koefisien Determinasi Tanpa Variabel Kontrol}

Model Summary

\begin{tabular}{|l|r|r|r|c|}
\hline Model & $\mathrm{R}$ & $\mathrm{R}$ Square & $\begin{array}{c}\text { Adjusted R } \\
\text { Square }\end{array}$ & $\begin{array}{c}\text { Std. Error of the } \\
\text { Estimate }\end{array}$ \\
\hline 1 &, $377^{\mathrm{a}}$ &, 142 &, 120 &, 20406375 \\
\hline
\end{tabular}

Tabel 4.10

\section{Uji Koefisien Determinasi Dengan Variabel Kontrol}

Model Summary

\begin{tabular}{|c|c|c|c|c|}
\hline Model & $\mathrm{R}$ & R Square & $\begin{array}{l}\text { Adjusted R } \\
\text { Square }\end{array}$ & $\begin{array}{l}\text { Std. Error of the } \\
\text { Estimate }\end{array}$ \\
\hline 1 &, $672^{a}$ & 451 & ,407 & 16760543 \\
\hline
\end{tabular}

Tabel 4.9 menunjukkan bahwa besarnya nilai adjusted $R$ squared yang hanya dipengaruhi oleh variabel konservatisme sebesar 0,120. Sedangkan pada tabel 4.10, model regresi yang telah ditambahkan variabel kontrol memiliki nilai nilai adjusted $R$ squared sebesar 0,407 yang berarti bahwa 40,7\% abnormal return saham pada saat pengumuman SEO dipengaruhi oleh konservatisme, size, dan leverage, dan sisanya 59,3\% dipengaruhi oleh variabel lain. Hal tersebut menunjukkan bahwa setelah adanya penambahan variabel kontrol berupa size dan leverage dalam model penelitian menjadi semakin baik.

\section{Kesimpulan dan saran}

Penelitian ini dilakukan dengan tujuan menguji pengaruh konservatisme terhadap abnormal return saham pada saat pengumuman SEO. Konservatisme diukur dengan menggunakan pendekatan net asset measures dikarenakan sampel yang digunakan dalam penelitian mencakup seluruh bidang perusahaan. Jumlah sampel yang digunakan dalam penelitian ini berjumlah 42 perusahaan dari tahun 2011 sampai dengan tahun 2013.

Berdasarkan hasil pengujian atas data yang telah dikumpulkan, kesimpulan yang diperoleh adalah konservatisme berpengaruh positif signifikan terhadap abnormal return saham pada saat pengumuman SEO.

Keterbatasan yang terdapat dalam penelitian ini adalah sampel yang digunakan dalam penelitian hanya hanya perusahaan yang melakukan SEO dan tanggal pengumuman hasil RUPS dapat diperoleh dari idx.co.id dan public domain yang dapat diakses dengan mudah dan gratis, sehingga sampel yang digunakan relatif sedikit.

Berdasarkan keterbatasan yang terdapat dalam penelitian ini, saran yang diberikan untuk penelitian selanjutnya adalah memperbanyak jumlah sampel yang akan diteliti agar hasil penelitian dapat digeneralisasikan. 


\section{Daftar Pustaka}

Adiwiratama, Jundan. 2012. Pengaruh Informasi Laba, Arus Kas, dan Size Perusahaan Terhadap Return Saham. Jurnal Ilmiah Akuntansi dan Humanika. Vol. 2 No.1.

Christanty, Pang Ruth Shinta. 2003. Analisis Perbedaan Abnormal Return Saham di Seputar Tanggal Pengumuman Right Issue. Universitas Atma Jaya Yogyakarta.

Ghozali, Imam. 2009. Aplikasi Analisis Multivariate Dengan Program SPSS. Semarang: Badan Penerbit UNDIP.

Gulnur Maragdoglu. 2008. “An Empirical Tes on Leverage and Stock Return”. Cash Business School. London International Jurnal.

Gunanta, Remon. 2013. Pengaruh Konsevatisme Akuntansi Terhadap Return Saham Yang Dimoderasi oleh Kepemilikan Institusional. Journal \& Proceeding Universitas Jenderal Soedirman. Vol. 3 No. 1.

Handojo, Irwanto. 2012. Sekelumit Konservatisme Akuntansi. STIE Trisakti. Jakarta.

Haniati, Sri. 2010. Pengaruh Konservatisme Terhadap Asimetri Informasi Dengan Menggunakan Beberapa Model Pengukuran Konservatisme. Simposium Nasional Akuntansi XIII Purwokerto.

Hartono, Jogiyanto. 2012. Metodologi Penelitian Bisnis : "Salah Kaprah dan PengalamanPengalaman". Yogyakarta : BPFE.

Kasmis. 2010. Pengantar Manajemen Keuangan. Jakarta: Kencana.

Kieso, Donald E., Jerry J. Weygandt, Terry D. Warfield. 2011. Intermediate Accounting, Volume 1. United States of America: Wiley.

Kim, Yongtae., Carrie Pan, dan Luo Zuo. 2013. The Role of Accounting Conservatism In The Equity Market: Evidence from Seasoned Equity Offerings. The Accounting Review. Vol. 88, No. 4: 1327 - 1356.

Murwaningsari, Etty., Ardy P. C Nugraha. 2010. Relevansi Nilai Konservatisme Beserta Beberapa Faktor Yang Mempengaruhi. Jurnal Informasi, Perpajakan, Akuntansi, dan Keuangan Publik. Vol. 5, No. 1: 21 - 39.

Putri, Negina K., Refius P. S., Ekaningtyas W. 2006. Pengaruh Kinerja Operasi Jangka Panjang Sebagai Indikasi Manajemen Laba Pada Perusahaan Manufaktur Yang Melakukan Seasoned Equity Offerings Di Bursa Efek Jakarta. Universitas Jenderal Soedirman. Purwokerto.

Sulistyanto, Sri., Haris Wibisono. 2003. Seasoned Equity Offerings : Antara Agency Theory, Windows of Opportunity, dan Penurunan Kinerja. Simposium Nasional Akuntansi VI.

Sulistyanto, Sri. 2008. Manajemen Laba: Teori dan Model Empiris. Jakarta : Grasindo.

Sugiyono. 2001. Statistika Untuk Penelitian. Bandung: Alfabeta.

Tandelilin, Eduardus. 2010. Portofolio dan Investasi : Teori dan Aplikasi. Yogyakarta : Kanisius.

Wardhani, Ratna. 2008. Tingkat Konservatisme Akuntansi di Indonesia dan Hubungannya dengan Karakteristik Dewan sebagai Salah Satu Mekanisme Corporate Governance. Simposium Nasional Akuntansi XI.

Wibisono, Haris. 2004. Pengaruh Manajemen Laba Terhadap Kinerja Perusahaan Di Seputar Seasoned Equity Offerings (Studi Empiris di Bursa Efek Jakarta). Universitas Diponegoro. Semarang.

Widya. 2004. Faktor-Faktor Yang Mempengaruhi Pilihan Perusahaan Terhadap Akuntansi Konservatif. Simposium Nasional Akuntansi VII. 